\title{
Effect of Growing Miscanthus $x$ giganteus on Soil Microbial Communities in Post-Military Soil
}

\author{
Diana Nebeská $^{1, *}$, Josef Trögl ${ }^{1}{ }^{1}$, Valentina Pidlisnyuk ${ }^{1}$, Jan Popelka ${ }^{1}{ }^{\mathbb{D}}$, \\ Petra Veronesi Dáňová ${ }^{1}$, Sergej Ust' ak ${ }^{2}$ (i) and Roman Honzík ${ }^{2}$ (i) \\ 1 Faculty of Environment, Jan Evangelista Purkyně University in Ústí nad Labem, Králova Výšina 3132/7, \\ 40096 Ústí nad Labem, Czech Republic; josef.trogl@ujep.cz (J.T.); valentyna.pidlisniuk@ujep.cz (V.P.); \\ jan.popelka@ujep.cz (J.P.); petra.danova@ujep.cz (P.V.D.) \\ 2 Crop Research Institute, Drnovská 507/73, 16106 Praha 6 Ruzyně, Czech Republic; ustak@eto.vurv.cz (S.U.); \\ honzik@eto.vurv.cz (R.H.) \\ * Correspondence: diana.nebeska@ujep.cz; Tel.: +420-475-284-113
}

Received: 23 September 2018; Accepted: 30 October 2018; Published: 2 November 2018

check for updates

\begin{abstract}
Growing a second generation energetic plant Miscanthus $x$ giganteus $(\mathrm{M} x g)$ in former military sites appears to be a promising way to use such areas with synergic phytoremediation of contaminants (organic pollutants, potential toxic metals). Effect of $M x g$ growth on soil microbial communities during a two-year pot experiment with real post-military soil (Sliač, Slovakia) and the effect of potential toxic metal concentration was studied by analyses of microbial activities and phospholipid fatty acids (PLFA). Year-on-year positive changes in microbial community structure and state were detected (higher ratios of G+/G- bacteria and fungal/bacterial PLFA, and a decrease of stress indicators trans/cis and cy/pre PLFA). Portion of gram-positive bacteria correlated negatively with potential toxic metal concentrations; however, the concentration of potential toxic metals was not identified as the main stress factor-the access to bioavailable nutrients was more important. Overall, $M x g$ growth generally exhibited a positive effect on soil microorganisms.
\end{abstract}

Keywords: soil microbial communities; phytoremediation; Miscanthus x giganteus; post-military site; phospholipid fatty acids; extracellular enzyme activities

\section{Introduction}

Contamination of the environment after military activities is widely spread, and it can tremendously affect biodiversity, as well as the state of groundwater and soil resources [1]. Formal military sites and their conversion for future civilian use still remain a challenge for many countries of Central and Eastern Europe. Many of these sites successfully transformed into natural protected zones [2,3] —however, contamination still prevents some of these areas from their potential beneficial use. Post-military sites are mostly contaminated by organic pollutants, such as petroleum or chlorinated hydrocarbons (PAHs) and potential toxic metals (PTMs) (e.g., $\mathrm{Cu}, \mathrm{Pb}, \mathrm{Cd}, \mathrm{Cr}$, and As), especially at former shooting ranges $[4,5]$. Growing second-generation biofuel crops like $C_{4}$ perennial grass Miscanthus $x$ giganteus $(\mathrm{M} x g$ ) appears to be a promising way to productively use these large abandoned lands for biomass production [6-9]. Mxg is able to grow in military soil slightly contaminated by PTMs without significant metal extraction and relocation to the shoot part of plant [8-11]. Besides phytoextraction, the potential of $M x g$ for phytostabilization [12,13] and the phytodegradation $[14,15]$ of pollutants in contaminated soil was studied, which together leads to the possibility of restoring post-military sites with simultaneous economic profit.

Soil microorganisms play a key role in providing soil functions and ecosystem services [16], which include, among others, the biodegradation of petroleum products [17]. The microorganisms are 
sensitive to stress caused by PTM contamination [18,19]. The same effect was confirmed for As, with a greater impact on bacteria compared to fungi [20]. Therefore, the presence of high concentrations of PTMs (e.g., $\mathrm{Cu}, \mathrm{Cd}, \mathrm{Pb}, \mathrm{Zn}, \mathrm{Ni}[21,22], \mathrm{Hg}$, and $\mathrm{Cr}^{\mathrm{VI}}$ ) [22] in soil can complicate the process of bioremediation significantly. On the other hand, small concentrations of some microelements $(\mathrm{Cu}$, $\mathrm{Mn}$ ) [23] can accelerate bioremediation. These effects should also be considered during the planning of the remediation approach for post-military sites. Growing $M x g$ can support the development of soil microbial communities, increase enzymatic activity through the multiple effects of PTM phytostabilization, increased the income of organic carbon to soil [13], and prevent soil erosion by root system [24].

In our previous study, we explored the possibility of growing $M x g$ in post-military soil and PTM phytoextraction [9]. The aim of this sequel study is to investigate the influence of growing $M x g$ in soil microbial communities and the activities of various extracellular enzymes in post-military soil with various concentrations of PTMs during two vegetation seasons. Phospholipid fatty acid profiling, a method well-established in soil ecology [25], was used for estimation of the biomass of dominant microbial groups and determination of microbial stress indicators. Rhizosphere and bulk soil was determined separately, in an attempt to distinguish the direct effect of plant roots.

\section{Materials and Methods}

\subsection{Experiment}

The two-year greenhouse pot experiment was established as described previously [9]. Briefly, a series of pots with a mixture of soil from a former military site (Sliač, Slovakia) and control agricultural soil from the locality situated nearby was prepared. Both localities are situated in a region with a high concentration of As in soil. The source of As is mainly geogenic, coming from ores, such as arsenopyrite in fluvial sediments along the Hron river, which flows through the research area [26]. This post-military site was additionally affected by military activities in the Sliač airport. Soil mixtures were prepared in five different ratios with two repetitions. For statistical evaluation in this article, soil variants were sorted into three groups according to PTM concentration: control, low, and high (Table 1). Two rhizomes of $M x g$ were planted in each pot and grown in a greenhouse for two vegetation seasons.

Table 1. Concentrations of metals in mixtures of post-military and control soils (average \pm standard deviation; $n=2)$ [9].

\begin{tabular}{cccccc}
\hline Soil Variant & Control & \multicolumn{2}{c}{ Low } & \multicolumn{2}{c}{ High } \\
\hline control soil & $100 \%$ & $75 \%$ & $50 \%$ & $25 \%$ & $0 \%$ \\
post-military soil & $0 \%$ & $25 \%$ & $50 \%$ & $75 \%$ & $100 \%$ \\
\hline As [mg/kg] & $290 \pm 40$ & $515 \pm 15$ & $430 \pm 79$ & $465 \pm 15$ & $425 \pm 45$ \\
Cu [mg/kg] & $310 \pm 0$ & $380 \pm 60$ & $395 \pm 5$ & $440 \pm 100$ & $565 \pm 125$ \\
Fe [mg/kg] & $174,555 \pm 5395$ & $194,485 \pm 8645$ & $205,640 \pm 7540$ & $209,480 \pm 6830$ & $215,210 \pm 5720$ \\
Mn [mg/kg] & $2995 \pm 185$ & $3605 \pm 485$ & $4110 \pm 340$ & $4495 \pm 555$ & $4660 \pm 500$ \\
Sr [mg/kg] & $685 \pm 65$ & $695 \pm 15$ & $925 \pm 15$ & $1185 \pm 75$ & $1200 \pm 40$ \\
Ti [mg/kg] & $20,620 \pm 0$ & $24,410 \pm 260$ & $25,935 \pm 615$ & $27,940 \pm 2420$ & $28,170 \pm 530$ \\
Zn [mg/kg] & $960 \pm 90$ & $1025 \pm 45$ & $1115 \pm 115$ & $1205 \pm 335$ & $1015 \pm 235$ \\
Zr $[\mathrm{mg} / \mathrm{kg}]$ & $1275 \pm 275$ & $1455 \pm 75$ & $1345 \pm 205$ & $1500 \pm 60$ & $1625 \pm 225$ \\
\hline
\end{tabular}

\subsection{Sampling}

Soil for the experiment was sampled from the top layer $(0-0.3 \mathrm{~m})$, in accordance with the standard approach [27] as described earlier [9].

After the first and second year of vegetation, two different soil samples were taken from the pots. Approximately $100 \mathrm{~g}$ of bulk soil from the top of each pot and rhizosphere soil was taken close to the $M x g$ roots, at a distance up to $3 \mathrm{~mm}$. After transportation, part of the soil was frozen down to $-40{ }^{\circ} \mathrm{C}$ for phospholipid fatty acid (PLFA) analysis; the rest of analyses were carried out within 14 days, with soil stored in a refrigerator $\left(5^{\circ} \mathrm{C}\right)$. 


\subsection{Analyses}

Samples were tested for available nutrients (P, K, Ca, and $\mathrm{Mg}$ ) in extracts, according to Mehlich [28], and for total $\mathrm{N}$ and $\mathrm{S}$ concentrations by elementary analysis using a Vario MAX CNS/CN analyzer after digestion by sulphuric acid, as described previously [29]. The total organic carbon was determined by a TOC analyzer (SKALAR Primacs ${ }^{\text {SLC }}$ ).

The amount of living microbial biomass and rough structure of the soil microbial community was assessed by simple extraction of phospholipid fatty acids (PLFAs) [25]. This method consists of four steps: (1) extraction of total lipids by a single-phase mixture of chloroform, methanol, and a phosphate buffer; (2) isolation of phospholipids by solid-phase extraction on silica columns; (3) mild alkaline methanolysis; and (4) determination of produced fatty acid methyl esters (FAME) by gas chromatography (Varian GC 3800), using a mass spectrometry detector (Varian MS 4000). The total concentration of PLFA was used as an indicator of living microbial biomass, and the content of indicator FAME was used for the estimation of particular microbial groups and the calculation of physiological indicators (general stress estimated as trans/cis value and nutrition stress, estimated as cy/pre) in accordance with [16], as follows: G+ bacteria i14:0, i15:0, a15:0, i17:0, and a17:0; G- bacteria

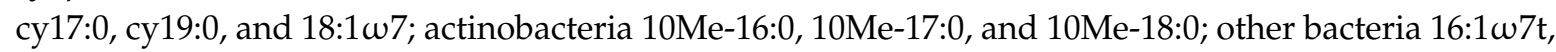

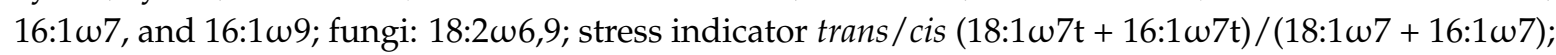

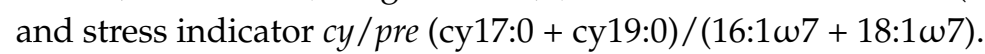

Extracellular enzyme activities were determined by direct incubation of the soil sample with artificial substrates, as described previously [29]. For enzymes representing biogeochemical cycles of important nutrients, p-nitrophenol substrates were used, specifically p-nitrophenyl phosphate disodium salt hexahydrate for phosphatases, L-alanine p-nitroanilide hydrochloride for proteases, and potassium p-nitrophenyl sulfate for arylsulphatases. For oxidases, the substrate 2,6-dimethoxyphenol was used, and for peroxidases 2,6-dimethoxyphenol with addition of $\mathrm{H}_{2} \mathrm{O}_{2}$ was used. Production of coloured p-nitrophenol $(\lambda=400 \mathrm{~nm})$ and 3,3',5,5'-tetramethoxydiphenylquinone $(\lambda=468 \mathrm{~nm})$ was measured spectrophotometrically by a microplate reader [29]. Basal soil respiration was measured as a rate of production of $\mathrm{CO}_{2}$ by its capture in $\mathrm{NaOH}$ and titration of residual $\mathrm{NaOH}$ after seven days of incubation with $1 \mathrm{~g}$ of soil [30].

\subsection{Statistics}

For statistical evaluation, soil variants were sorted into three groups, according to PTM concentration: control, low, and high (Table 1). Additionally, data were sorted according to the sampling season and root effect (rhizosphere and bulk soil).

Data were evaluated using the Statgrahics Centurion XVI and Past 3.17 statistical software packages. The Multifactor ANOVA (MANOVA) procedure was applied to construct a statistical model describing the impact of effects (season, root effect, and metal concentration). Principal component analysis (PCA) was consequently applied to display the correlation structure of soil microbial characteristics and the influence of the statistically most important effects. As the dependent variables (nutrients, soil microbial characteristics, etc.) were measured in different units (absolute and relative concertation units), the PCA was based on correlation (normalized var-covar) matrix.

\section{Results and Discussion}

\subsection{Soil Nutrients}

According to Czech legislation classification [31], the content of available P in samples varied from low to very high, available $\mathrm{K}$ from good to very high and available $\mathrm{Mg}$ was very high in all tested samples. While $\mathrm{K}, \mathrm{Mg}$, and $\mathrm{Ca}$ concentrations did not differ significantly across the tested groups, concentrations of available P varied across all samples (Table 2). Based on these facts, no statistically significant trend was observed between seasons or metal concentrations. Total $\mathrm{S}$ and $\mathrm{N}$ in soil decreased significantly from year to year (Table 3). Nevertheless, the source of these macro-elements was sufficient 
during the entire experiment. There was no significant difference between bulk and root soil, but metal concentrations in the soil positively correlated with content of N and TOC. In the preceding study [9], we observed no inhibition of $M x g$ growth, which could be attributed to the increased concentration of risk elements (dominantly As). Thus, the most contaminated variant was the most beneficial, from a nutrient point of view.

Table 2. Concentrations of nutrients in test soils (average \pm standard deviation). Th upper indexes indicate the number of repetitions $\left({ }^{\mathrm{a}} n=2,{ }^{\mathrm{b}} n=4\right)$.

\begin{tabular}{|c|c|c|c|c|c|}
\hline \multirow{2}{*}{ Soil Nutrients } & \multirow{2}{*}{$\begin{array}{c}\text { Metal } \\
\text { Concentration }\end{array}$} & \multicolumn{2}{|c|}{ 1st Season } & \multicolumn{2}{|c|}{ 2nd Season } \\
\hline & & $\begin{array}{c}\text { Rhizosphere } \\
\text { Soil }\end{array}$ & Bulk Soil & $\begin{array}{c}\text { Rhizosphere } \\
\text { Soil }\end{array}$ & Bulk Soil \\
\hline \multirow{3}{*}{$\begin{array}{l}\text { Available P } \\
{[\mathrm{mg} / \mathrm{kg}]}\end{array}$} & control & $49.9 \pm 38.2^{\mathrm{a}}$ & $45.8 \pm 38.0^{a}$ & $18.2 \pm 15.2^{\mathrm{a}}$ & $43.0 \pm 46.6^{a}$ \\
\hline & low & $90.1 \pm 43.5^{b}$ & $96.3 \pm 50.2^{b}$ & $90.1 \pm 46.2^{b}$ & $55.1 \pm 29.0^{b}$ \\
\hline & high & $128.0 \pm 107.0^{b}$ & $81.1 \pm 92.7^{b}$ & $127.1 \pm 110.5^{b}$ & $86.8 \pm 82.2^{b}$ \\
\hline \multirow{3}{*}{$\begin{array}{c}\text { Available K } \\
{[\mathrm{mg} / \mathrm{kg}]}\end{array}$} & control & $313.1 \pm 31.4^{\mathrm{a}}$ & $315.8 \pm 51.9^{a}$ & $269.4 \pm 18.5^{\mathrm{a}}$ & $299.9 \pm 73.5^{a}$ \\
\hline & low & $377.0 \pm 81.5^{\mathrm{b}}$ & $386.5 \pm 89.4^{b}$ & $327.2 \pm 27.4^{b}$ & $317.6 \pm 55.7^{b}$ \\
\hline & high & $416.1 \pm 169.5^{b}$ & $381.1 \pm 170.8^{b}$ & $346.4 \pm 121.3^{b}$ & $369.7 \pm 182.4^{b}$ \\
\hline \multirow{3}{*}{$\begin{array}{c}\text { Available Ca } \\
{[\mathrm{mg} / \mathrm{kg}]}\end{array}$} & control & $3130.0 \pm 30.3^{a}$ & $3273.0 \pm 233.7^{a}$ & $3106.4 \pm 49.6^{\mathrm{a}}$ & $3185.3 \pm 578.2^{a}$ \\
\hline & low & $3322.5 \pm 121.3^{b}$ & $3362.5 \pm 248.4^{b}$ & $3484.1 \pm 233.9^{b}$ & $3223.4 \pm 271.4^{b}$ \\
\hline & high & $3276.9 \pm 81.9^{b}$ & $3251.3 \pm 421.2^{b}$ & $3291.6 \pm 384.3^{b}$ & $3200.1 \pm 139.3^{b}$ \\
\hline \multirow{3}{*}{$\begin{array}{l}\text { Available Mg } \\
{[\mathrm{mg} / \mathrm{kg}]}\end{array}$} & control & $625.1 \pm 3.5^{\mathrm{a}}$ & $664.4 \pm 64.9^{\mathrm{a}}$ & $677.3 \pm 24.1^{\mathrm{a}}$ & $697.6 \pm 144.3^{a}$ \\
\hline & low & $658.1 \pm 24.6^{b}$ & $673.0 \pm 51.5^{b}$ & $713.7 \pm 104.3^{b}$ & $738.3 \pm 76.2^{b}$ \\
\hline & high & $634.5 \pm 54.1^{\mathrm{b}}$ & $721.4 \pm 120.1^{b}$ & $653.9 \pm 30.0^{\mathrm{b}}$ & $683.4 \pm 68.7^{b}$ \\
\hline \multirow{3}{*}{$\mathrm{N}_{\text {tot }}[\%]$} & control & $0.18 \pm 0.08^{a}$ & $0.19 \pm 0.09^{\mathrm{a}}$ & $0.14 \pm 0.01^{\mathrm{a}}$ & $0.16 \pm 0.09^{a}$ \\
\hline & low & $0.23 \pm 0.04^{b}$ & $0.24 \pm 0.05^{b}$ & $0.21 \pm 0.01^{b}$ & $0.20 \pm 0.05^{b}$ \\
\hline & high & $0.24 \pm 0.04^{b}$ & $0.28 \pm 0.07^{b}$ & $0.22 \pm 0.04^{b}$ & $0.23 \pm 0.03^{b}$ \\
\hline \multirow{3}{*}{$\mathrm{S}[\%]$} & control & $0.03 \pm 0.01^{\mathrm{a}}$ & $0.04 \pm 0.03^{a}$ & $0.02 \pm 0.00^{\mathrm{a}}$ & $0.02 \pm 0.02^{a}$ \\
\hline & low & $0.04 \pm 0.01^{b}$ & $0.04 \pm 0.01^{\mathrm{b}}$ & $0.03 \pm 0.01^{b}$ & $0.03 \pm 0.01^{b}$ \\
\hline & high & $0.03 \pm 0.00^{b}$ & $0.05 \pm 0.02^{b}$ & $0.03 \pm 0.00^{b}$ & $0.03 \pm 0.01^{b}$ \\
\hline \multirow{3}{*}{ TOC [\%] } & control & $2.27 \pm 1.01^{\mathrm{a}}$ & $2.07 \pm 1.04^{\mathrm{a}}$ & $2.28 \pm 0.36^{\mathrm{a}}$ & $1.97 \pm 0.88^{a}$ \\
\hline & low & $2.64 \pm 0.68^{b}$ & $2.89 \pm 0.74^{b}$ & $2.87 \pm 0.46^{b}$ & $3.06 \pm 1.26^{b}$ \\
\hline & high & $3.05 \pm 0.11^{b}$ & $3.40 \pm 0.50^{b}$ & $3.36 \pm 0.72^{b}$ & $3.14 \pm 0.79^{b}$ \\
\hline
\end{tabular}

Table 3. Impact of effects on nutrients (MANOVA: F-ratio statistic and its $p$-value; ${ }^{* *} p<0.05,{ }^{* * *} p<0.01$; $\uparrow$ indicates a significant increase or $\downarrow$ a significant decrease).

\begin{tabular}{cccccccc}
\hline Effect & $\mathbf{P}$ & $\mathbf{K}$ & $\mathbf{C a}$ & $\mathbf{M g}$ & $\mathbf{S}$ & $\mathbf{N}_{\text {tot }}$ & TOC \\
\hline 1st season $\times$ 2nd season & 0.27 & 1.90 & 0.03 & 1.72 & $9.75 \downarrow^{* * *}$ & $5.78 \downarrow^{* *}$ & 0.14 \\
rhizosphere $\times$ bulk & 1.02 & 0.00 & 0.32 & 2.82 & 2.15 & 0.67 & 0.08 \\
metals concentration & 2.72 & 1.49 & 1.37 & 0.63 & 1.38 & $7.74 \uparrow^{* * *}$ & $6.76 \uparrow^{* * *}$ \\
\hline
\end{tabular}

\subsection{Microbial Community}

Principal component analysis (PCA) (Figure 1) revealed relatively small variability of microbial community data. The two main principal components together explained $57 \%$ of data variability. PCA3 explained a further $11 \%$ of variability, and the other principal components explained below $8 \%$. The bi-plot revealed a difference between the first and second year vegetation seasons in both bulk and root soil. Also, the difference of microbial community composition in soils with different PTM concentrations was determined namely between the "control" and "high" groups. Nevertheless, the results for the rhizosphere and bulk soil were comparable. This was caused probably by limited space in the pot, since after a two-year period the entire space of the pot was fully grown through by Mxg roots. 


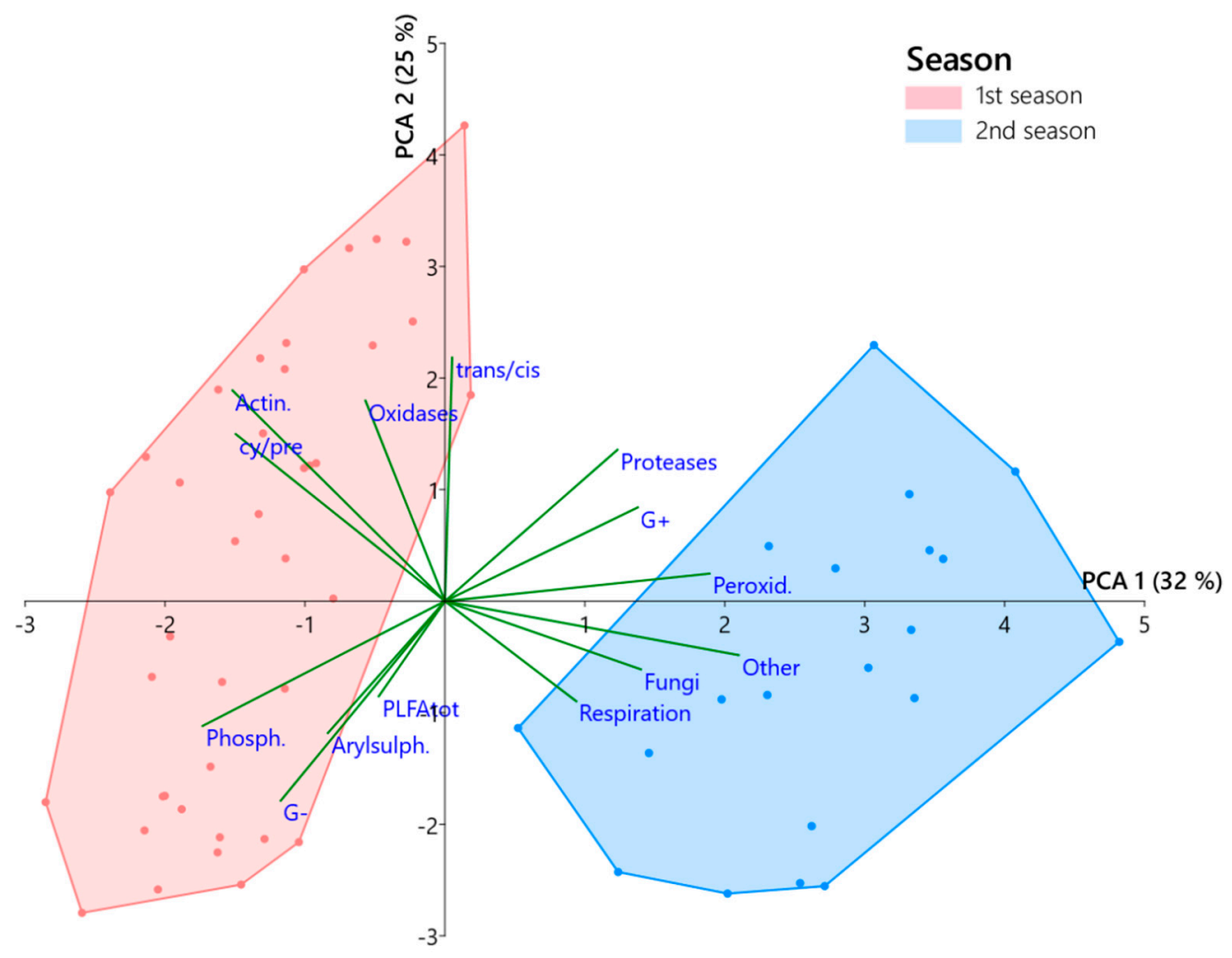

(a)

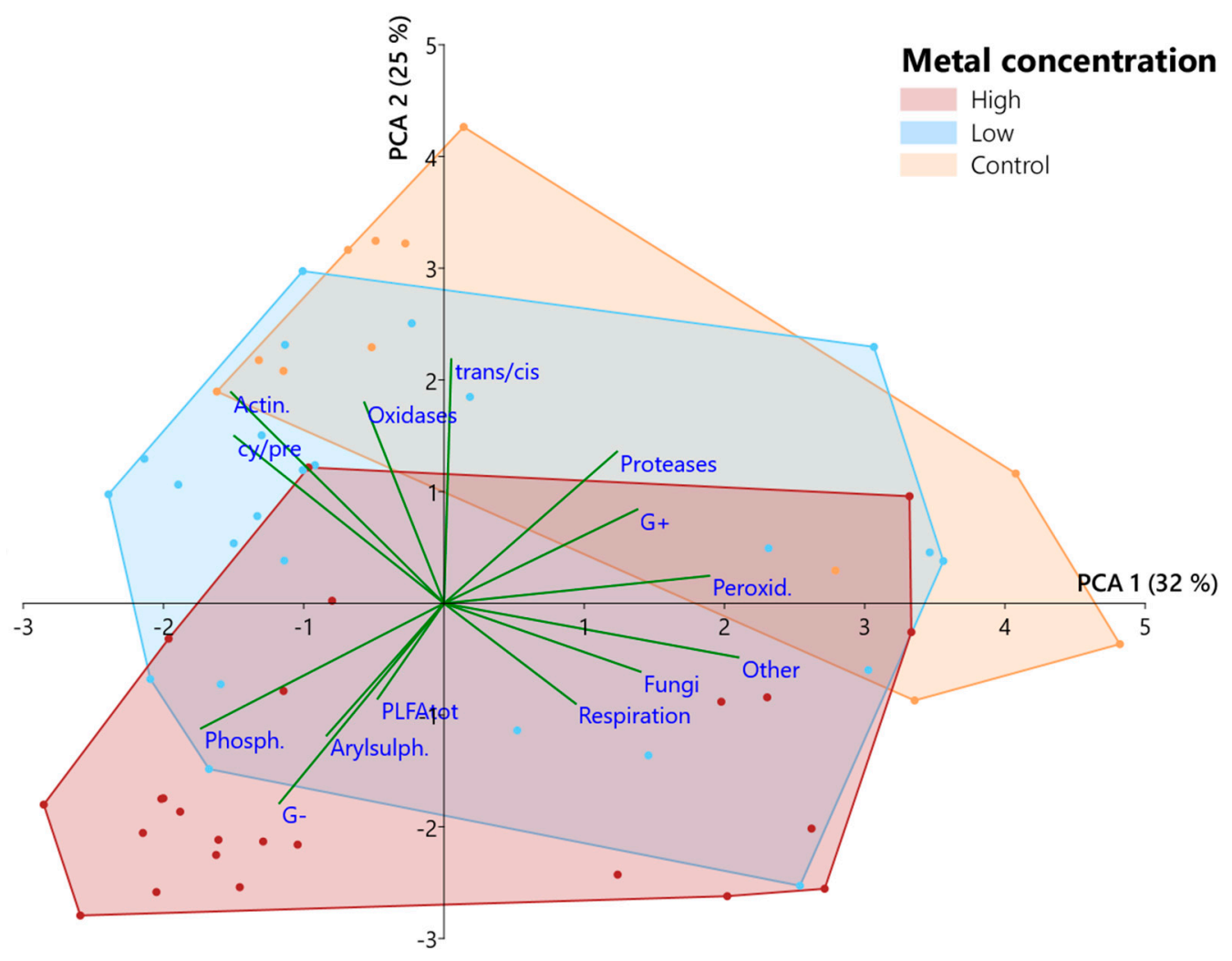

(b)

Figure 1. Principal component analyses (PCA) of soil microbial characteristics, and the influence of (a) season and (b) metal concentrations. 
There were significant changes in activity of extracellular enzymes, which represent the most important biogeochemical cycles of C, N, P, and S (Table 4). A seasonal decrease of $\mathrm{N}$ in the soil was accompanied by increased activity of proteases, while the activity of arylsulphatases was not accelerated by increased content of $\mathrm{S}$. Also, significantly decreased activity of phosphatases was determined. Activity of $\mathrm{N}$ (proteases) and $\mathrm{C}$ (oxidases and peroxidases) cycle enzymes correlated negatively with the concentration of PTMs. The opposite trend was observed for the activity of the phosphatases and arylsulphatases cycles.

Table 4. Impact of effects on extracellular enzyme activities (MANOVA: F-ratio statistic and its $p$-value;

*** $p<0.01 \uparrow$ indicates a significant increase or $\downarrow$ a significant decrease).

\begin{tabular}{ccccccc}
\hline Effect & Phosp. & Arylsulp. & Proteas. & Oxidas. & Peroxidas. & Respirat. \\
\hline 1st season $\times$ 2nd season & $55.71 \downarrow^{* * *}$ & 2.54 & $12.42 \uparrow * * *$ & $18.55 \downarrow^{* * *}$ & $117.98 \uparrow * * *$ & $8.03 \uparrow * * *$ \\
rhizosphere $\times$ bulk & 2.52 & 0.48 & 0.01 & 0.51 & 0.16 & 0.94 \\
metals concentration & $23.61 \uparrow^{* * *}$ & $7.07 \uparrow * * *$ & $9.70 \downarrow^{* * *}$ & $17.82 \downarrow^{* * *}$ & $11.44 \downarrow^{* * *}$ & 0.43 \\
\hline
\end{tabular}

Changes in the activities of extracellular soil enzymes are less unambiguous, as there are many factors that can affect them (total microbial biomass, availability of nutrients, quality of nutrients, stress factors, etc. [32,33]). The activities of hydrolyzes (in our case, phosphatases, arysulphatases, glucosidases, and peroxidases) are usually interpreted as elevated microbial efforts to gain the macrobiotic nutrients. For example, during soil development on clay spoil heaps, an increase of several hydrolases' activities was proportional to microbial biomass only for the first 21 years, after which they declined despite a further increase of biomass [34]. In nutrient-limited sandstone sediments, a negative correlation was observed between specific activities of hydrolases and their corresponding nutrients [29]. This assumption is in accordance with inter-seasonal decrease of total $\mathrm{N}$ accompanied by increase of protease activity. On the other hand, the activity of phosphatases (Figure 2) decreased, while the changes of bioavailable P were insignificant. Also, the total sulphur decreased inter-seasonally, while no significant changes in the activity of arylsulphatases was detected. Activities of peroxidases can be attributed dominantly to soil fungi, and their increase reflects the increase of fungal PLFA.

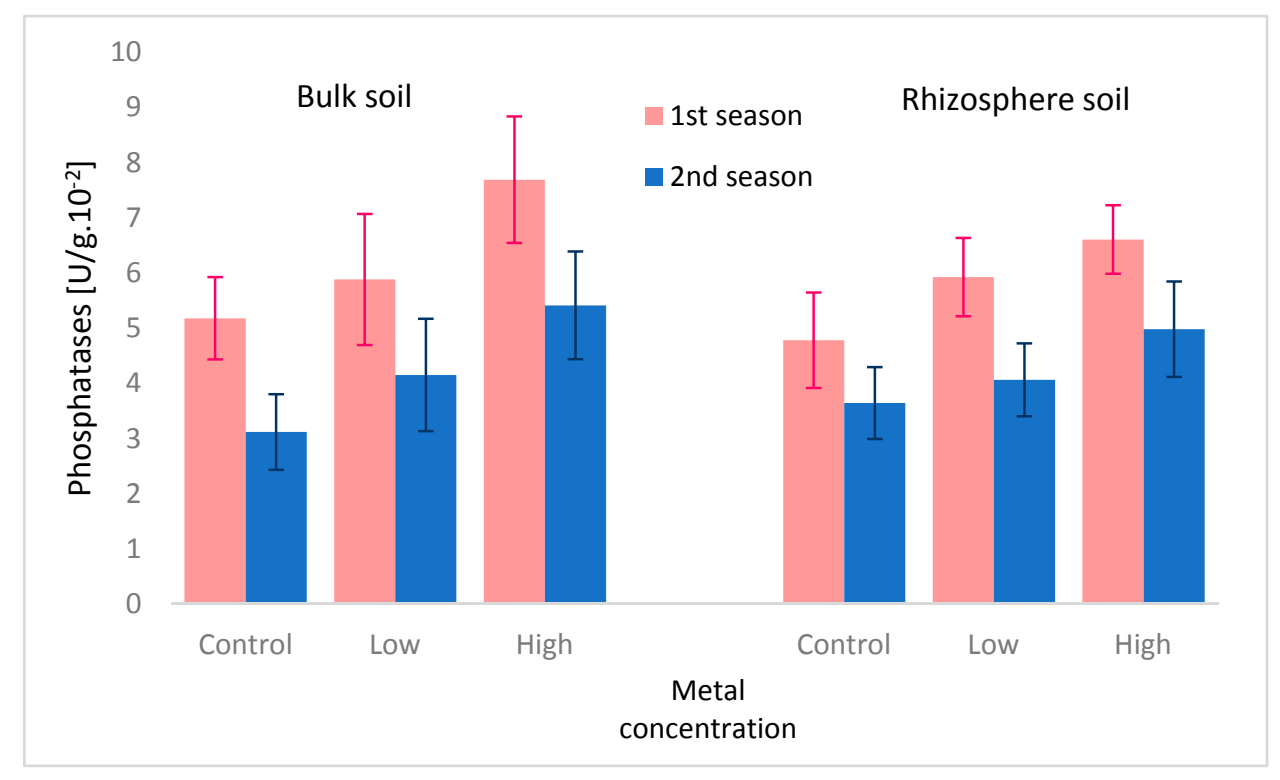

Figure 2. Phosphatase activity during the experiment.

Unlike in the study of Robertson et al. [35], soil respiration (Figure 3), referring to the overall activity of the microbial community and degradation of organic matter, increased significantly between first and second year. It may suggest the positive affect of plant growth on microbial activity, likely 
due to the secretion of root exudates [36]. This conclusion was supported by higher soil respiration in rhizosphere soil in second vegetation season.

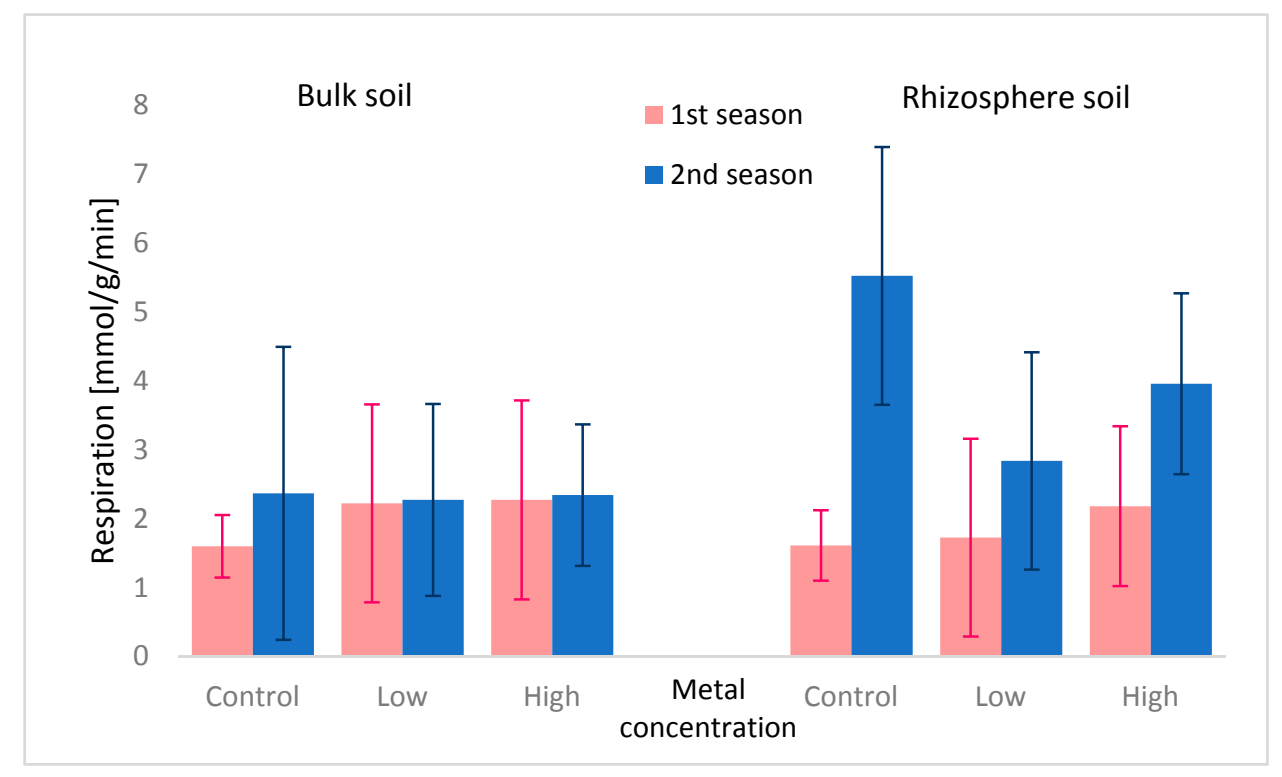

Figure 3. Soil respiration during experiment.

The total PLFA content was rather low $(3.22-8.32 \mathrm{mg} / \mathrm{kg}$; more details in Supplementary Materials). It was comparable, for example, with post-mining sites [34] or oil-contaminated soils before the start of the bioremediation process [37]. Positive trends in the annual development of soil microbial community state and structure could be identified (Table 5). They were indicated by increased ratios of G+/G- PLFA and F/B PLFA, and also by a significant decrease of stress indicators cy/pre and trans/cis PLFA (explanation in Appendix A). On the other hand, a portion of actinobacterial biomass $\left(\mathrm{PLFA}_{\mathrm{Ac}}\right.$ ) decreased. Together with an increase of fungal PLFA, this suggests normalization of the microbial community, since actinobacteria usually dominate in disturbed soils only [25]. On the other hand, this might be an undesired result, especially if $M x g$ was used for phytoremediation of organic pollutants, since many good bacterial degraders belong to the Actinobacteria phylum.

Table 5. Impact of effects on microbial community structure (MANOVA: F-ratio statistic and its $p$-value; ${ }^{*} p<0.1,{ }^{* *} p<0.05,{ }^{* * *} p<0.01$; $\uparrow$ indicates a significant increase or $\downarrow$ a significant decrease).

\begin{tabular}{ccccccc}
\hline Effect & PLFA $_{\mathbf{G +}}$ & PLFA $_{\mathbf{G}-}$ & PLFA Ac $_{\text {Ac }}$ & PLFA Fungi $^{\text {trans/cis }}$ & cy/pre \\
\hline 1st season $\times$ 2nd season & $13.82 \uparrow * * *$ & $6.27 \downarrow^{* *}$ & $176.94 \downarrow^{* * *}$ & $27.64 \uparrow^{* * *}$ & $2.92 \downarrow^{*}$ & $82.77 \downarrow^{* * *}$ \\
rhizosphere $\times$ bulk & 0.00 & 0.29 & 0.58 & 0.98 & $3.27 \uparrow *$ & $7.61 \uparrow * * *$ \\
metals concentration & 1.01 & $8.87 \uparrow * * *$ & $28.77 \downarrow^{* * *}$ & 0.19 & $17.54 \downarrow^{* * *}$ & $10.41 \downarrow^{* * *}$ \\
\hline
\end{tabular}

Significantly lower values of both stress indicators trans/cis (Figure 4) and cy/pre (Figure 5) in the rhizosphere compared to bulk soil suggest that contact with roots contributes to the elimination of stress factors affecting the microbial community. PLFA stress indicators were significantly lower in variants with higher concentration of PTMs. Because this soil was also richer in nutrients, it suggests that nutrient deficiency was a more important stress factor then the presence of PTMs in soil. Such a result is positive for possible applications of phytodegradation (rhizodegradation) for soils simultaneously contaminated by biodegradable organics and PTMs. Nevertheless, the concentration of PTMs in soil correlated negatively with G+/G- PLFA. A higher tolerance of G- bacteria should be considered, in the case of choosing an appropriate bacterial species for bioaugmentation combined with phytoremediation in similarly contaminated sites, such as military sites. 


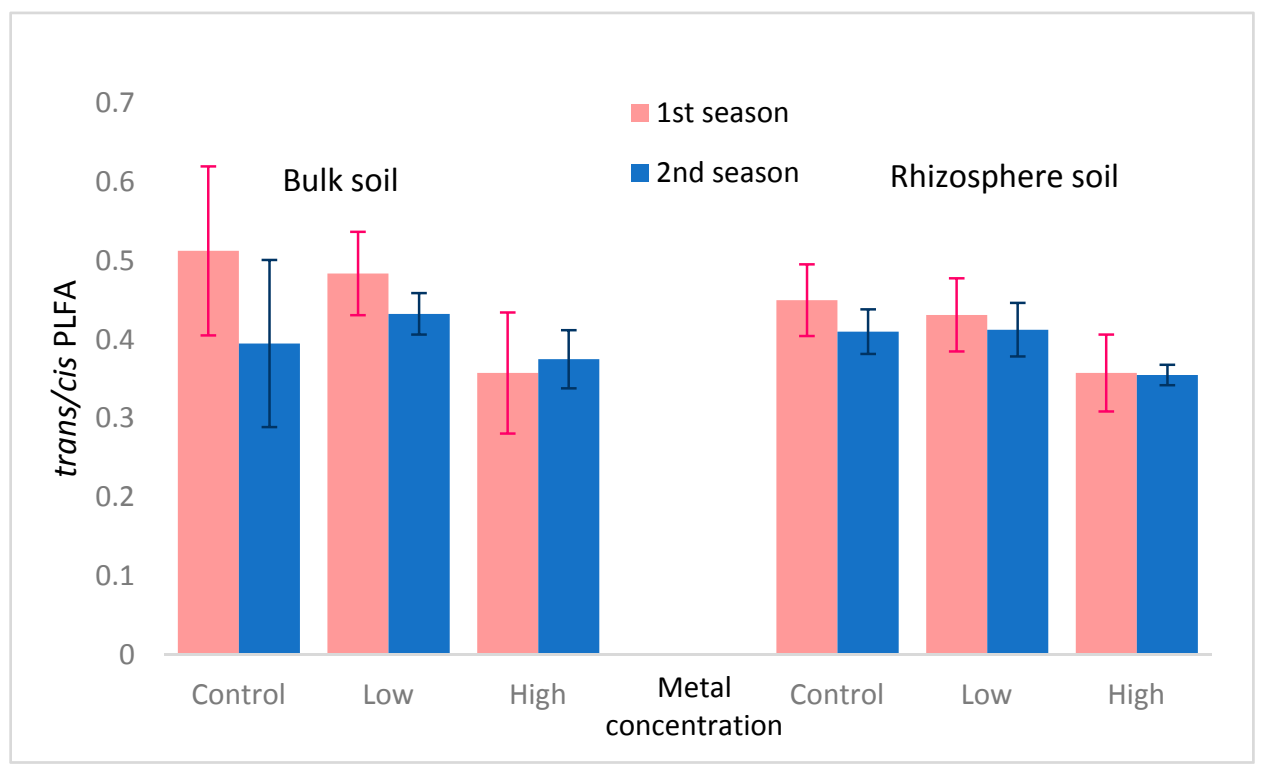

Figure 4. Trans / cis phospholipid fatty acid (PLFA) physiological indicators during the experiment.

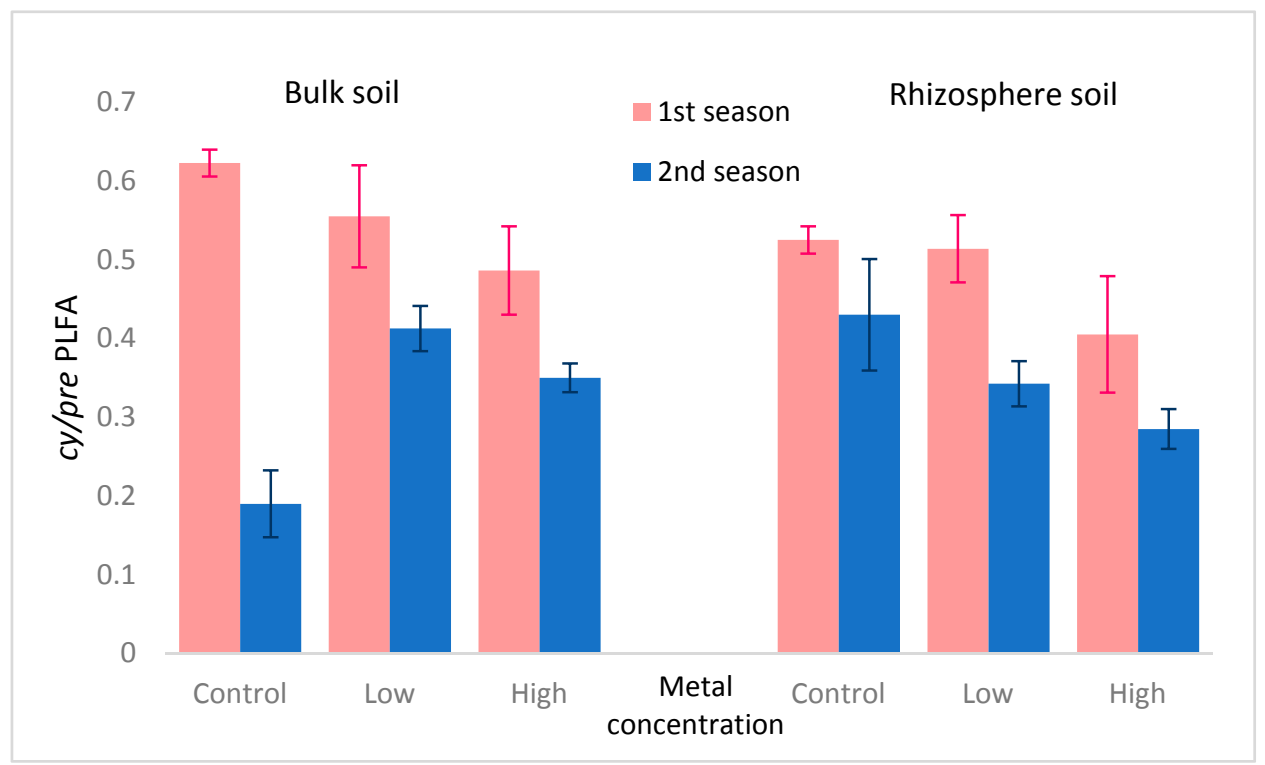

Figure 5. Cy/pre PLFA physiological indicators during the experiment.

\subsection{Implications for Sustainable Development}

Second-generation biofuel crops are considered sustainable, as they should be capable of reaching several sustainability goals simultaneously [38]—i.e., extensive production of utilizable biomass without a significant input of external energy, useful utilization of land inapplicable for food production (such as contaminated sites), and improvement of soil characteristics [39]. Growing perennial grasses over the long term can be considered to be the emulation of the pedogenesis of highly fertile soils, such as chernozems. Despite the fact that our two-year experiment presents only an episode in the long-term pedogenesis, overall positive indicators of soil development were detected. This especially includes the decrease of PLFA stress indicators trans/cis and cy/pre, an increase of soil respiration, and a decrease of enzyme activities indicating improvement of nutrient stress. On the other hand, a few indicators showed negative trends, especially the significant decrease of total nitrogen and sulphur.

The obtained results come from the two-year pot experiment only. A longer time would be needed to gain more significant data; however, a longer experiment was not possible [9]. We therefore consider 
these results as a case study that should bring a single piece to the future mosaic. It was recently indicated that $M x g$ cultivated in pots exhibited a higher stress response against PTM stress compared to field-cultivated $M x g$ [40]. Together with optimized conditions in the greenhouse, the processes in our experiment could have been accelerated compared to real field conditions. Also, the results shall be verified in the field experiment on real soils.

Positive changes of $M x g$ growth on the microbial community were reached despite PTMs in soil. The results indicate that with the proper determination of available nutrients in soil, and with reasonable fertilization if needed, the development of microbial biomass can be supported by growing $M x g$, even in soils contaminated by PTMs, such as former military sites. It can lead to soil function improvement, and also to enhanced biodegradation of oil products, which are often present with PTMs together in military soils, as it was in case of the Sliač site [4]. Because soil contamination and eventual subsequent contamination of water resources may also negatively affect the health of the ecosystem and inhabitants of the area, this process of phytoremediation contributes also to public health improvement. All of these positive effects, together with the possibility of using biomass directly for energy production; for processing into biofuels [7,41]; or as a material for other products, like paper [42] or building materials [43], can contribute to the successful reclamation of former military sites. Because phytoremediation is a low-cost method of soil restoration, it can also be used in developing countries, and $M x g$ biomass production can support local economic and energy independence.

\section{Conclusions}

During two years' pot growth of second-generation energetic crop Miscanthus $x$ giganteus in real post-military soil, significant changes of microbial indicators were determined, suggesting positive development in the soil microbial community. The concentration of total phospholipid fatty acids (PLFA), an indicator of living microbial biomass, remained unchanged. However, the proportion of indicators of dominant microbial groups changed significantly towards the values of undisturbed soils. Also, the PLFA stress indicators trans/cis and cy/pre decreased significantly, and the soil respiration increased. Changes in soil enzyme activities were, however, less clear. The lower availability of nutrients was revealed to be a more important stress factor for soil microorganisms than presence of PTMs. Although confirmation in field experiments is important, the results indicate that growing $M x g$ appears to be a promising way to effectively use large areas of post-military sites, and simultaneously support microorganisms in soils during phytoremediation process. Nevertheless, these results must be confirmed by long-term field research in real conditions.

Supplementary Materials: The following are available online at http:/ / www.mdpi.com/2071-1050/10/11/4021/ s1, Table S1: Soil microbial characteristics in test soils (average \pm standard deviation), upper indexes indicate number of repetitions ( $\left.{ }^{\mathrm{a}} n=2,{ }^{\mathrm{b}} n=4,{ }^{\mathrm{c}} n=8\right)$.

Author Contributions: D.N. carried out the PLFA analyses, evaluation of the data and drafting and finalization of the manuscript. J.T. contributed to data evaluation and interpretation and manuscript drafting. V.P. designed the original experiment and carried out sampling, she also contributed to manuscript drafting. J.P. performed statistical evaluation and prepared the figures. P.V.D. carried out determination of enzyme activities and respirations as well as TOC analyses. S.U. and R.H. carried out analyses of the soil parameters.

Funding: This research was funded by NATO Science for Peace and Security MYP G4687 and Jan Evangelista Purkyně University Student internal grant UJEP-SGS-2017-44-003-3.

Conflicts of Interest: The authors declare no conflict of interest.

\section{Appendix A. Explanation of the Physiological Indicators}

Physiological indicator trans/cis is based on the fact that majority of fatty acids are in cis configuration, while isomeration to trans configuration in bacteria is considered as a rapid protective mechanism (trans fatty acids can be more densely organized in the membrane) [25]. In bacteria, this isomeration takes place directly in the membrane catalyzed by isomerase enzymes, without the need for phospholipid decomposition and de-novo synthesis [25,44]. 
The $c y /$ pre indicator is based on the observation that gram-negative bacteria tend to synthesize cyclopropylated fatty acids (especially cy17:0 and cy19:0) by the direct addition of methylene to a double bond of unsaturated fatty acids upon transition to a stationary growth phase. This takes place usually as a result of nutrient insufficiency, but can be caused by other stress factors also. The indicator can be used only if there is a significant proportion of G-bacterial PLFA [45].

\section{References}

1. Fonnum, F.; Paukstys, B.; Zeeb, B.A.; Reimer, K.J. Environmental Contamination and Remediation Practices at Former and Present Military Bases; Paukštys, B., Fonnum, F., Zeeb, B.A., Reimer, K.J., Eds.; Springer: Dordrecht, The Netherlands, 1998; ISBN 978-0-7923-5248-8.

2. Gazenbeek, A. LIFE, Natura 2000 and the Military; Office for Official Publications of the European Communities: Luxembourg, 2005; ISBN 92-894-9213-9.

3. Ellwanger, G.; Müller, C.; Ssymank, A.; Vischer-Leopold, M.; Paulsch, C. Management of Natura 2000 Sites on Military Training Areas; Landwirtschaftsverlag: Münster, Germany, 2016; ISBN 978-3-7843-9172-4.

4. DANCEE; Andersern, J.N. Management of Contaminated Sites and Land in Central and Eastern Europe; Danish Environmental Protection Agency: Copenhagen, Denmark, 2000; ISBN 87-7909-889-4. Available online: https:/ / www2.mst.dk/udgiv/publications/2000/87-7909-888-6/html/default_eng.htm (accessed on 2 November 2018).

5. Nadtochiy, P.P.; Bilyavs'kyy, Y.A.; Myslyva, T.M.; Shmahala, Y.B. The problems of rehabilitation of the ground-landed resources of Zhytomyr oblast, muddy as a result of military activity. BICHИ041A ЖHAEУ (VISNYK ZHNAEU) 2009, 2, 14-32. (In Ukrainian)

6. Fazio, S.; Monti, A. Life cycle assessment of different bioenergy production systems including perennial and annual crops. Biomass Bioenergy 2011, 35, 4868-4878. [CrossRef]

7. van der Weijde, T.; Alvim Kamei, C.L.; Torres, A.F.; Vermerris, W.; Dolstra, O.; Visser, R.G.F.; Trindade, L.M. The potential of C4 grasses for cellulosic biofuel production. Front. Plant Sci. 2013, 4, 107. [CrossRef] [PubMed]

8. Pidlisnyuk, V.; Trögl, J.; Stefanovska, T.; Shapoval, P.; Erickson, L. Preliminary Results on Growing Second Generation Biofuel Crop Miscanthus x giganteus at The Polluted Military Site in Ukraine. Nova Biotechnol. Chim. 2016, 15, 77-84. [CrossRef]

9. Pidlisnyuk, V.V.; Erickson, L.E.; Trögl, J.; Shapoval, P.Y.; Popelka, J.; Davis, L.C.; Stefanovska, T.R.; Hettiarachchi, G.M. Metals uptake behaviour in Miscanthus $x$ giganteus plant during growth at the contaminated soil from the military site in Sliač, Slovakia. Pol. J. Chem. Technol. 2018, 20, 1-7. [CrossRef]

10. Nsanganwimana, F.; Pourrut, B.; Waterlot, C.; Louvel, B.; Bidar, G.; Labidi, S.; Fontaine, J.; Muchembled, J.; Lounès-Hadj Sahraoui, A.; Fourrier, H.; et al. Metal accumulation and shoot yield of Miscanthus $\times$ giganteus growing in contaminated agricultural soils: Insights into agronomic practices. Agric. Ecosyst. Environ. 2015, 213, 61-71. [CrossRef]

11. Andrejić, G.; Gajić, G.; Prica, M.; Dželetović, Ž.; Rakić, T. Zinc accumulation, photosynthetic gas exchange, and chlorophyll a fluorescence in Zn-stressed Miscanthus $\times$ giganteus plants. Photosynthetica 2018, 56, 1249-1258. [CrossRef]

12. Iqbal, M.; Bermond, A.; Lamy, I. Impact of miscanthus cultivation on trace metal availability in contaminated agricultural soils: Complementary insights from kinetic extraction and physical fractionation. Chemosphere 2013, 91, 287-294. [CrossRef] [PubMed]

13. Al Souki, K.S.; Louvel, B.; Douay, F.; Pourrut, B. Assessment of Miscanthus x giganteus capacity to restore the functionality of metal-contaminated soilsEx situ experiment. Appl. Soil Ecol. 2017, 115, 44-52. [CrossRef]

14. Nsanganwimana, F.; Pourrut, B.; Mench, M.; Douay, F. Suitability of Miscanthus species for managing inorganic and organic contaminated land and restoring ecosystem services. A review. J. Environ. Manag. 2014, 143, 123-134. [CrossRef] [PubMed]

15. Techer, D.; Martinez-Chois, C.; Laval-Gilly, P.; Henry, S.; Bennasroune, A.; D'Innocenzo, M.; Falla, J. Assessment of Miscanthus $\times$ giganteus for rhizoremediation of long term PAH contaminated soils. Appl. Soil Ecol. 2012, 62, 42-49. [CrossRef]

16. Trögl, J.; Pavlorková, J.; Packová, P.; Seják, J.; Kuráň, P.; Popelka, J.; Pacina, J. Indication of Importance of Including Soil Microbial Characteristics into Biotope Valuation Method. Sustainability 2016, 8, 253. [CrossRef] 
17. Das, N.; Chandran, P. Microbial Degradation of Petroleum Hydrocarbon Contaminants: An Overview. Biotechnol. Res. Int. 2011, 2011, 1-13. [CrossRef] [PubMed]

18. Giller, K.E.; Witter, E.; Mcgrath, S.P. Toxicity of heavy metals to microorganisms and microbial processes in agricultural soils: A review. Soil Biol. Biochem. 1998, 30, 1389-1414. [CrossRef]

19. Dai, J.; Becquer, T.; Rouiller, J.H.; Reversat, G.; Bernhard-Reversat, F.; Lavelle, P. Influence of heavy metals on $\mathrm{C}$ and $\mathrm{N}$ mineralisation and microbial biomass in $\mathrm{Zn-}, \mathrm{Pb}-, \mathrm{Cu}-$, and $\mathrm{Cd}$-contaminated soils. Appl. Soil Ecol. 2004, 25, 99-109. [CrossRef]

20. Hiroki, M. Effect of arsenic pollution on soil microbial population. Soil Sci. Plant Nutr. 1993, 39, $227-235$. [CrossRef]

21. Goswami, L.; Arul Manikandan, N.; Pakshirajan, K.; Pugazhenthi, G. Simultaneous heavy metal removal and anthracene biodegradation by the oleaginous bacteria Rhodococcus opacus. 3 Biotech 2017, 7, 37. [CrossRef] [PubMed]

22. Riis, V.; Babel, W.; Pucci, O.H. Influence of heavy metals on the microbial degradation of diesel fuel. Chemosphere 2002, 49, 559-568. [CrossRef]

23. Zukauskaite, A.; Jakubauskaite, V.; Belous, O.; Ambrazaitiene, D.; Stasiskiene, Z. Impact of heavy metals on the oil products biodegradation process. Waste Manag. Res. 2008, 26, 500-507. [CrossRef] [PubMed]

24. Chibuike, G.U.; Obiora, S.C. Heavy Metal Polluted Soils: Effect on Plants and Bioremediation Methods. Appl. Environ. Soil Sci. 2014, 2014, 1-12. [CrossRef]

25. Kaur, A.; Chaudhary, A.; Kaur, A.; Choudhary, R.; Kaushik, R. Phospholipid fatty acid-A bioindicator of environment monitoring and assessment in soil ecosystem. Curr. Sci. 2005, 89, 1103-1112. [CrossRef]

26. Pažická, A.; Brčeková, J.; Klimko, T.; Jurkovič, L'.; Pet’ková, K.; Kordík, J.; Slaninka, I. Characteristics of geogenic and anthropogenic sources of potentially toxic trace elements in selected stream sediments of Slovakia based on geochemical and mineralogical evaluation. Miner. Slovaca 2014, 45, 117-126.

27. DSTU ISO 11464-2001: Soil Quality. Preliminary Preparation of Samples for Physicalchemical Analysis; DSTU: Kyiv, Ukraine, 2001.

28. Mehlich, A. Mehlich 3 soil test extractant: A modification of Mehlich 2 extractant. Commun. Soil Sci. Plant Anal. 1984, 15, 1409-1416. [CrossRef]

29. Kukla, J.; Holec, M.; Trögl, J.; Holcová, D.; Hofmanová, D.; Kuráň, P.; Popelka, J.; Pacina, J.; Kř́iženecká, S.; Ust'ak, S.; et al. Tourist Traffic Significantly Affects Microbial Communities of Sandstone Cave Sediments in the Protected Landscape Area “Labské Pískovce" (Czech Republic): Implications for Regulatory Measures. Sustainability 2018, 10, 396. [CrossRef]

30. Frouz, J.; Cajthaml, T.; Kř́bek, B.; Schaeffer, P.; Bartuška, M.; Galertová, R.; Rojík, P.; Krištůfek, V. Deep, subsurface microflora after excavation respiration and biomass and its potential role in degradation of fossil organic matter. Folia Microbiol. 2011, 56, 389-396. [CrossRef] [PubMed]

31. 275/1998 Sb. Vyhláška Ministerstva Zemědělství o Agrochemickém Zkoušení Zemědělských půd a Zjišt'ování Půdních Vlastností Lesních Pozemků. Available online: http://eagri.cz/public/web/ws_ content? contentKind=regulation\&section=1\&id=46970\&name=275/1998 (accessed on 31 October 2018).

32. Burns, R.G.; DeForest, J.L.; Marxsen, J.; Sinsabaugh, R.L.; Stromberger, M.E.; Wallenstein, M.D.; Weintraub, M.N.; Zoppini, A. Soil enzymes in a changing environment: Current knowledge and future directions. Soil Biol. Biochem. 2013, 58, 216-234. [CrossRef]

33. Sinsabaugh, R.L.; Lauber, C.L.; Weintraub, M.N.; Ahmed, B.; Allison, S.D.; Crenshaw, C.; Contosta, A.R.; Cusack, D.; Frey, S.; Gallo, M.E.; et al. Stoichiometry of soil enzyme activity at global scale. Ecol. Lett. 2008, 11, 1252-1264. [CrossRef] [PubMed]

34. Baldrian, P.; Trögl, J.; Frouz, J.; Šnajdr, J.; Valášková, V.; Merhautová, V.; Cajthaml, T.; Herinková, J. Enzyme activities and microbial biomass in topsoil layer during spontaneous succession in spoil heaps after brown coal mining. Soil Biol. Biochem. 2008, 40, 2107-2115. [CrossRef]

35. Robertson, A.D.; Davies, C.A.; Smith, P.; Stott, A.W.; Clark, E.L.; McNamara, N.P. Carbon Inputs from Miscanthus Displace Older Soil Organic Carbon without Inducing Priming. Bioenergy Res. 2017, 10, 86-101. [CrossRef]

36. Técher, D.; Laval-Gilly, P.; Henry, S.; Bennasroune, A.; Formanek, P.; Martinez-Chois, C.; D’Innocenzo, M.; Muanda, F.; Dicko, A.; Rejšek, K.; et al. Contribution of Miscanthus x giganteus root exudates to the biostimulation of PAH degradation: An in vitro study. Sci. Total Environ. 2011, 409, 4489-4495. [CrossRef] [PubMed] 
37. Kuráň, P.; Trögl, J.; Nováková, J.; Pilařová, V.; Dáňová, P.; Pavlorková, J.; Kozler, J.; Novák, F.; Popelka, J. Biodegradation of Spilled Diesel Fuel in Agricultural Soil: Effect of Humates, Zeolite, and Bioaugmentation. Sci. World J. 2014, 2014, 1-8. [CrossRef] [PubMed]

38. United Nations. A/RES/70/1 Transforming Our World: The 2030 Agenda for Sustainable Development; United Nations: New York, NY, USA, 2015.

39. Pidlisnyuk, V.; Stefanovska, T.; Lewis, E.E.; Erickson, L.E.; Davis, L.C. Miscanthus as a Productive Biofuel Crop for Phytoremediation. CRC Crit. Rev. Plant Sci. 2014, 33, 1-19. [CrossRef]

40. Bastia, G.; Al Souki, K.; Liné, C.; Pourrut, B. Phytoremediation studies: Comparison between in situ and ex situ experiments results. In Proceedings of the 15th International Phytotechnology Conference (Phytotechnologies and Forestry: Sustainable Approaches to Mitigating the Environmental Consequences of Climate Change), Novi Sad, Serbia, 1-5 October 2018.

41. Lee, W.-C.; Kuan, W.-C. Miscanthus as cellulosic biomass for bioethanol production. Biotechnol. J. 2015, 10, 840-854. [CrossRef] [PubMed]

42. Cappelletto, P.; Mongardini, F.; Barberi, B.; Sannibale, M.; Brizzi, M.; Pignatelli, V. Papermaking pulps from the fibrous fraction of Miscanthus x Giganteus. Ind. Crops Prod. 2000, 11, 205-210. [CrossRef]

43. Courard, L.; Parmentier, V. Carbonated miscanthus mineralized aggregates for reducing environmental impact of lightweight concrete blocks. Sustain. Build. 2017, 2, 3. [CrossRef]

44. Moore-Kucera, J.; Dick, R.P. PLFA Profiling of Microbial Community Structure and Seasonal Shifts in Soils of a Douglas-fir Chronosequence. Microb. Ecol. 2008, 55, 500-511. [CrossRef] [PubMed]

45. Frostegård, Å.; Tunlid, A.; Bååth, E. Use and misuse of PLFA measurements in soils. Soil Biol. Biochem. 2011, 43, 1621-1625. [CrossRef]

(C) 2018 by the authors. Licensee MDPI, Basel, Switzerland. This article is an open access article distributed under the terms and conditions of the Creative Commons Attribution (CC BY) license (http:/ / creativecommons.org/licenses/by/4.0/). 